\title{
腎盂尿管移行部狭窄症および尿管狭窄症に対する内視鏡的 腎孟尿管切開術拉よび透視下尿管切開術の試み
}

\author{
岐阜県立岐阜病院泌尿器科 \\ 竹内 敏視 長谷 行洋 小出 卓也 酒井 俊助 \\ 大垣市民病院泌尿器科 \\ 米田 尚生 藤本 佳則 堀江 正宣 磯貝 和俊 \\ トヨ夕記念病院泌尿器科 \\ 前田 真一 \\ 厚生会木澤病院泌尿器科 \\ 石原哲松田聖士 \\ 岐阜大学医学部泌尿器科学教室（主任：河田幸道教授） \\ 山本 直樹篠田育男兼松稔河田幸道
}

\section{ENDOSCOPIC AND FLUOROSCOPIC PYELOURETEROTOMY FOR URETEROPELVIC JUNCTION OBSTRUCTION AND URETERAL STRICTURE}

\author{
Toshimi Takeuchi, Yukihiro Nagatani, Takuya Koide and Shunsuke Sakai \\ Department of Urology, Gifu Prefectural Hospital \\ Hisao Komeda, Yoshinori Fujimoto, Masanobu Horie and Kazutoshi Isogai \\ Department of Urology, Ogaki Municipal Hospital \\ Shinichi Maeda \\ Department of Urology, Toyota Memorial Hospital \\ Satoshi Ishihara and Seishi Matsuda \\ Department of Urology, Kizawa Hospital
}

Naoki Yamamoto, Ikuo Shinoda, Minoru Kanematsu and Yukimichi Kawada

Department of Urology, Gifu University School of Medicine

(Director: Prof. Y. Kawada)

Endoscopic or fluoroscopic pyeloureterotomy was performed in a total of 32 patients (34 ureters) with ureteropelvic junction obstruction (UPJO) or ureteral stricture from March 1985. Cold incision was performed, using a flexible knife over a guidewire, endoscopically on 23 ureters and fluoroscopically on 11 ureters. The mean operation time was $98.9 \pm 48.3$ minutes. Twenty-five (74\%) of the 34 ureters showed relief of subjective symptoms, normalized urinalysis and radiographical improvement of hydronephrosis with a mean follow-up period of $11.7 \pm 10.0$ months (range: $3 \sim 43$ ). The clinical results by etiology were as follows: primary UPJO, 13/16 (81\%); secondary UPJO, 4/4 (100\%); ureteral stricture, 6/7 (85\%); obliteration of ureteral implantation, $2 / 7$ (29\%). No major complication was noted with this endourological technique.

This endourological technique might be clinically useful for the treatment of UPJO and ureteral strictures.

Key words: endopyelotomy, ureterotomy, ureteral stricture

要旨: 我々は試作したワイヤーガイド可能な軟性切開刀を用いて, 32例（34尿管）の腎孟尿管移行部狭
窄症および尿管狭窄症に対して, 内視鏡的腎孟尿管切開術あるいは透視下尿管切開術を行い, その臨床
的意義を検討した. 狭窄部の切開は 25 尿管では経皮的に, 9 尿管では経尿道的あるいはストーマから逆 
行性に軟性切開力を挿入したらえで，23尿管では内視鏡的に，11尿管では透視下に切開を行った．ステ ント技去後 3 カ月を経過した 34 尿管中 25 尿管 $(74 \%)$ ）閉塞性変化の改善が認められた。成因別には先 天性腎孟尿管移行部狭窄症では16尿管中13尿管 (81\%)，後天性孟尿管移行部狭窄症では 4 尿管中 4 尿管 (100\%)，尿管狭窄症では 7 尿管中 6 尿管 $(85 \%) ，$ 尿管腸管吻合部や尿管膀朕吻合部の狭窄症では 7 尿 管中 2 尿管 (29\%) に改善が認められた。改善例の観察期間は平均 $11.7 \pm 10.0$ カで，重篤な合併症は 経験しなかった。試作した軟性切開刀を用いた内視鏡的腎孟尿管切開術および透視下尿管切開術は腎孟 尿管移行部狭窄症や尿管狭窄症に対し，侵襲の少ない，有用な尿路形成術と考兄られた。 キーワード：内視鏡的腎孟切開術，透視下尿管切開術，尿管狭窄症

\section{緒言}

上部尿路閉塞性病変のらち, 狭窄長が短い良性尿管 狭窄症や術後狭窄症は拡張バルンカテーテルを用いた 尿管拡張術により優れた効果が得られる12). しかし， 腎孟尿管移行部狭窄症あるいは高度尿管狭窄症では拡 張術を行っても，その反応は不良である2). 最近，腎盎 尿管移行部狭窄症に対しては内視鏡的腎盘切開術 ${ }^{3) \sim 6)}$ が行われるようになったが，我々はワイヤーガイド可 能な軟性の切開刀を試作し7)，内視鏡的腎盘尿管切開 術および透視下尿管切開術を行ったのでその臨床的意 義を検討した。

\section{対象および方法}

1986年 3 月より1990年 2 月までの 48 月の間に岐阜 県立岐阜病院，大垣市民病院，トヨ夕記念病院，厚生 会木澤病院および岐阜大学医学部附属病院において48 例 (51尿管) に対して内視鏡的腎盘尿管切開術あるい は透視下尿管切開術を施行した。このらちステント技 去後 3 力月以上を経過した 32 例，34尿管を対象とした (Table 1)。年齢は 9 カ月ょり 76歳（平均 $36.2 \pm 23.8$ 歳)で，このうち15歳未満の小児例は 6 尿管であった. 13尿管は腎皿形成術, 腎盘あるいは尿管切石術, 尿管 回腸吻合術などの既往を有し， 2 尿管は本法施行前に 抎張バルンカテーテルによる尿管拡張術が行われてい た。また11尿管は結石を合併し，11尿管は感染性水腎 症や腎機能障害のためにあらかじめ経皮的腎瘻造設術 が行われていた。

内視鏡的腎孟尿管切開術の方法は諸家3) 6) と同様, 経尿道的に尿管カテーテルを腎盘に插入し，経皮的腎 瘻作成後, 腎盘内のカテーテルを取り出し, 外尿道口 と腎瘻部の間に0.038インチのガイドワイヤーを wire-loop した. 次に, 硬性腎孟鏡下に $18 \mathrm{~F}$ 抎張バルン カテーテルを用いて, 予め狭窄部の拡張を手圧下に 行った後, ガイドワイヤーに沿わせて試作の軟性切開 刀を直視下に狭窄部まで挿入した。腎昷尿管移行部で は後側壁, 尿管では側壁, 膀胱近接部では前内側壁を
Table 1 Patient characteristics

\begin{tabular}{lr}
\hline Total number (pts) : & 32 (34 units) \\
Age (yrs), & \\
range : & $0.7-76$ \\
mean \pm SD : & $36.2 \pm 23.8$ \\
Sex (pts), & 20 \\
male : & 12 \\
female : & \\
Previous surgery (units), & 3 \\
pyelolithotomy : & 1 \\
pyeloplasty : & 2 \\
ureterolithotomy : & 2 \\
ureterovesicostomy : & 3 \\
ureteroileostomy : & 2 \\
ureterosigmoidostomy : & 2 \\
failed ureteral dilation : & 11 \\
Associated calculi (pts) : & 11 \\
Previous nephrostomy (units) : & \\
\hline
\end{tabular}

全層切開し，狭窄部の遠位・近位の正常尿管が観察さ れるまで長めに切開することを原則とした（Fig. 1, 2). 切開後, 腎孟尿管移行部狭窄症では30F, 尿管狭窄 症では18F の拡張バルンカテーテルによる拡張を再度 行い，尿管ステントを 6 週間留置した，尿管狭窄症や 尿管腸管吻合部狭窄症では，硬性尿管鏡あるいは胆道 ファイバーにより内視鏡的に細径軟性切開刀を用いて 切開した.ささらに最近では経皮的あるいは経尿道的に 軟性切開刀のみをガイドワイヤーに沿わせて㨀入し, 狭窄部の切開を行ら透視下尿管切開術を試みた（Fig. 3）. ステント技去後, 経時的に尿検查, 超音波検査, 排泄性腎孟造影,レノグラムを行い, 経過を観察した。 なお臨床症状, 尿検査所見とともに, 川村ら ${ }^{8)}$ おび江 左ら ${ }^{8}$ の分類に従い, 水腎症の変化の術後評価を行っ た。

\section{結果}

32例に用いた麻酔法の内訳は全身麻酔20例, 硬膜外 麻酔 7 例, 先椎麻酔 3 例, 局所麻酔 2 例であった. 狭 
Fig. 1 Intraoperative films of endopyelotomy in 8 year-old-boy. A. Retrograde pyelogram. B. Retrograde ureteral catheterization. C. $18 \mathrm{~F}$ balloon dilation. D. Pyelotomy under endoscopic control.

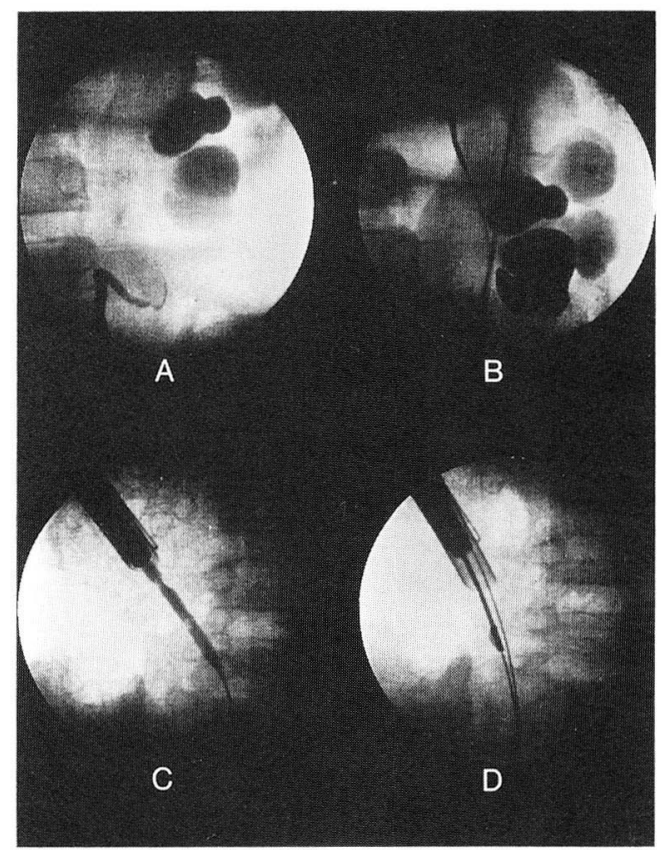

窄部の切開に際し，25尿管では経皮的に，9尿管では 経尿道的あるいはストーマから逆行性に軟性切開刀を 插入した (Table 2). 実際の切開は23尿管では内視鏡 的に，11尿管では透視下に切開を行った，手術時間は 30 205分, 平均 $98.9 \pm 48.3$ 分であった. ステントは初 期10尿管には8F C-Flex stent (Cook Urological Inc. ,
Table 2 Procedures

\begin{tabular}{lr}
\hline Introduction of wire (units), \\
antegrade : & 12 \\
retrograde : & 22 \\
Approach of flexible knife (units), \\
antegrade : & 25 \\
retrograde : & 9 \\
Control of incision (units), & \\
endoscopic : & 23 \\
fluoroscopic : & 11 \\
Operation time (min), & \\
range : & $30-205$ \\
mean \pm SD : & $98.9 \pm 48.3$ \\
Size of stent (units), & \\
$8 \mathrm{~F}:$ & 10 \\
$10 \mathrm{~F}:$ & 5 \\
$12 \mathrm{~F}:$ & 19 \\
\hline
\end{tabular}

USA) やスプリントカテーテルなどを使用したが，最 近の24尿管では10Fあるいは12F Endopyelotomy stent（Cook Urological Inc., USA）を使用した。 ス テントの留置時間は平均 $29.2 \pm 13.4$ 日, 入院期間は 2

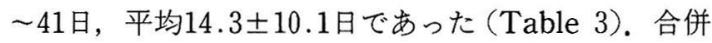
症としてステント留置期間中に腎皿腎炎が 6 例みら れ，2 例にステントの遠位端の尿管粘膜への刺激によ ると考えられる尿管閉塞が認められた。この尿管閉塞 例には拡張バルンカテーテルによる尿管拡張術を施行 した，そのほか術中輪血を要する出血が 1 例にみられ 術中輪血を要する出血が 1 例にみられた以外, 重篤な 合併症は経験しなかった。

臨床症状あるいは異常所見のうち，側腹部痛や血尿

Fig. 2 Intraoperative films of fluoroscopic pyelotomy in 9 month-infant with persistent ureteral infolding. A. Antegrade pyelogram. B. $18 \mathrm{~F}$ balloon dilation. C. Pyelotomy under fluoroscopic control.

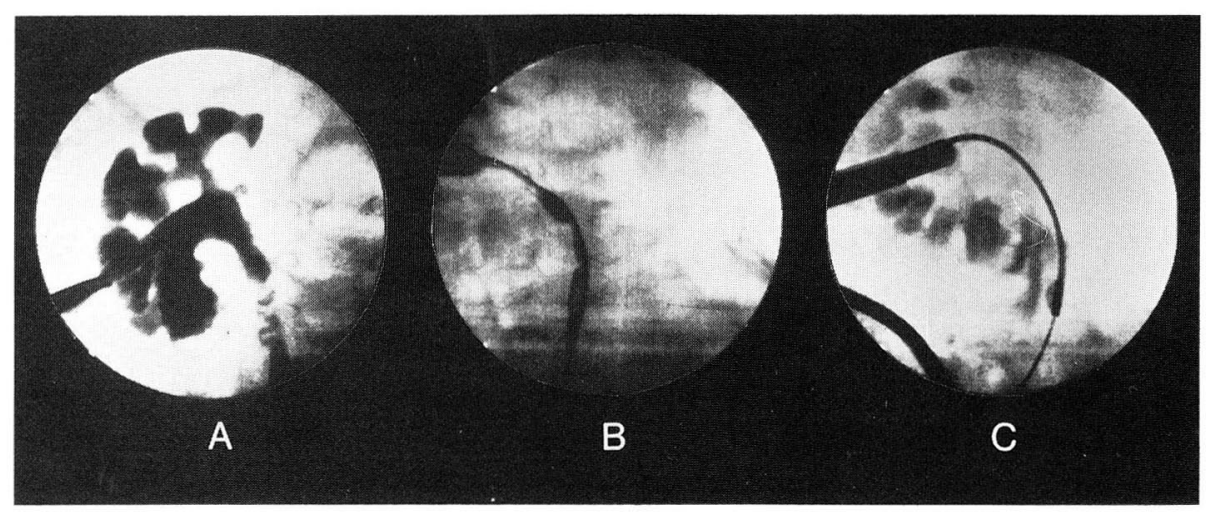


Fig. 3 Intraoperative films of fluoroscopic ureterotomy in 17-year-old-man with ureteral stricture of solitary kidney. A. Antegrade pyelogram. B. Percutaneous ureterotomy under fluoroscopic control.

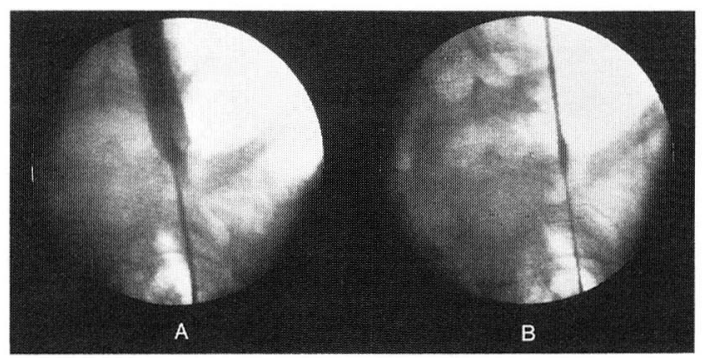

Table 3 Postoperative course

\begin{tabular}{lr}
\hline Complication (pts), & \\
pyelonephritis : & 6 \\
obstruction of stent : & 2 \\
hemorrhage : & 1 \\
Duration of stent (dys), & \\
range : & $5-68$ \\
mean \pm SD : & $29.2 \pm 13.4$ \\
Hospital stay (dys), & \\
range : & $2-41$ \\
mean \pm SD : & $14.3 \pm 10.1$ \\
\hline
\end{tabular}

はそれぞれ89\%，100\%の例に消失したが，尿管腸管吻 合部や移植尿管膀胱吻合部の狭窄症例に観察された膿 尿あるいは腎機能異常は存続した（Table 4)。尿管ス
Table 4 Effects on clinical manifestation

\begin{tabular}{l|c|c|c}
\hline & $\begin{array}{l}\text { No. of } \\
\text { pts }\end{array}$ & $\begin{array}{l}\text { Relieved } \\
\text { or improved }\end{array}$ & Persist \\
\hline Flank pain & 27 & $24(89 \%)$ & 3 \\
Abdominal mass & 2 & $2(100 \%)$ & 0 \\
Pyuria & 14 & $9(64 \%)$ & 5 \\
Hematuria & 10 & $10(100 \%)$ & 0 \\
Decreasing renal function & 4 & 0 & 4 \\
\hline
\end{tabular}

テント技去後, 川村ら ${ }^{8)}$ の分類で閉塞性変化の改善が 認められたものは25尿管 $(74 \%)$, 不変のものは 8 㽷管 (24\%)，増悪したものは 1 尿管（3％)であった（Fig. 4〜6). また江左ら 99 分類ではそれぞれ26尿管

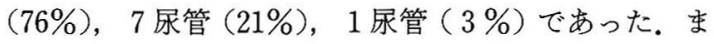
た部位あるいは成因別に評価すると，先天性腎血尿管 移行部狭窄症では16尿管中13尿管 $(81 \%)$ ，後天性腎孟 尿管移行部狭窄症では 4 尿管とも，尿管狭窄症では 7 尿管中 6 尿管 $(88 \%)$ に改善が認められたのに対し, 尿管腸管吻合部や移植尿管膀胱部の狭窄症では 7 尿管 中わずか 2 尿管 (29\%)に改善がみられたにすぎなかっ た (Table 5)。また15歳未満の小児 6 例中 5 例および 尿管拡張術不応の 2 例とも改善が認められた（Figs. 6, 7). これら改善例の観察期間は $3 \sim 43$ 力月, 平均 $11.7 \pm 10.0$ カ月であったが, 改善例のうら先天性腎盂 尿管移行部狭窄症の 1 例において, 難治性腎孟炎のた め開放性腎昷形成術を行った。 また不変あるいは増悪 の9尿管のうち, 腎瘻カテーテル留置を継続している ものが 4 尿管, 移植尿管膀胱再吻合術を施行したもの

Fig. 4 Changes of hydronephrosis.

- UPJO ; $\mathbf{\square}$, ureteral stricture ; $\boldsymbol{\Delta}$, obliteration of ureteral implantation.

1. Kawamura's grading system

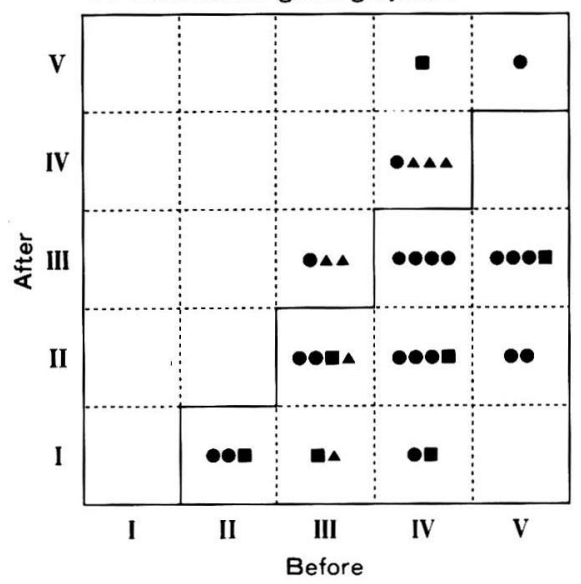

2. Esa's grading system

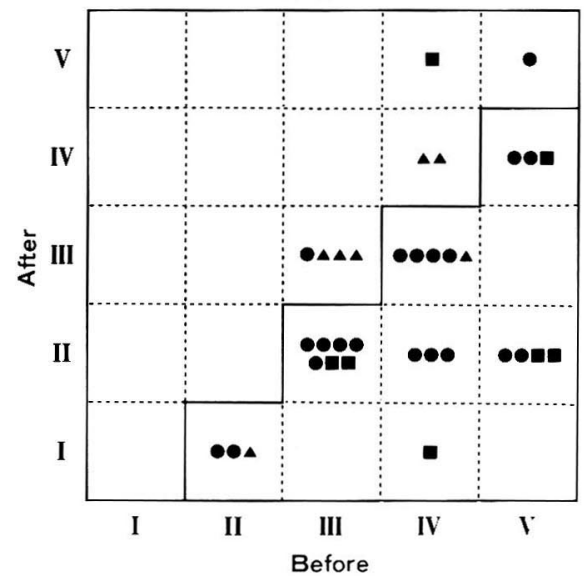


Table 5 Summary of outcome by endoscopic and fluoroscopic pyeloureterotomy

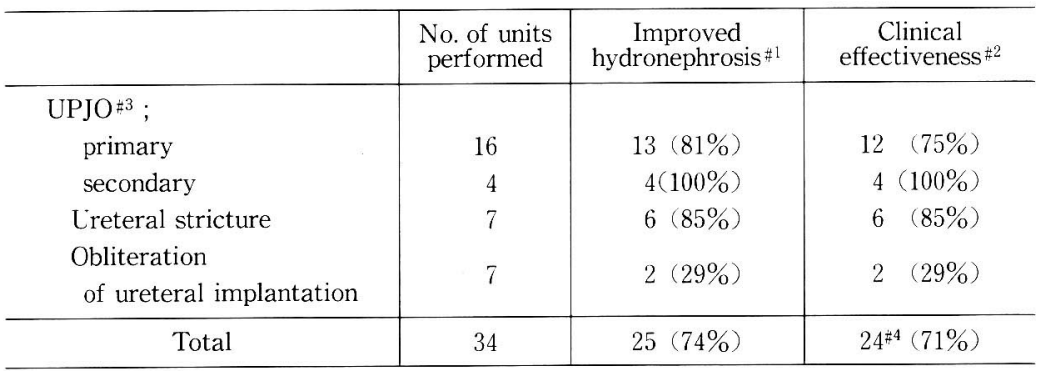

\#1 improvement of more than 1 grade of hydronephrosis by Kawamura's grading system. $\# 2$ evaluated by relief of subjective symptoms, normal urinalysis and improvement of hydronephrosis after removal of stent.

${ }^{3}$ ureteropelvic junction obstruction.

$\# 4$ mean follow-up period (mos) of $11.7 \pm 10.0$ (range : $3-43$ ).

Fig. 5 DIP of 59 year-old woman of primary ureteropelvic obstruction. A. Before. B. After. Postoperative pyelogram shows resolution of pyelocaliectasis and smaller renal pelvis.

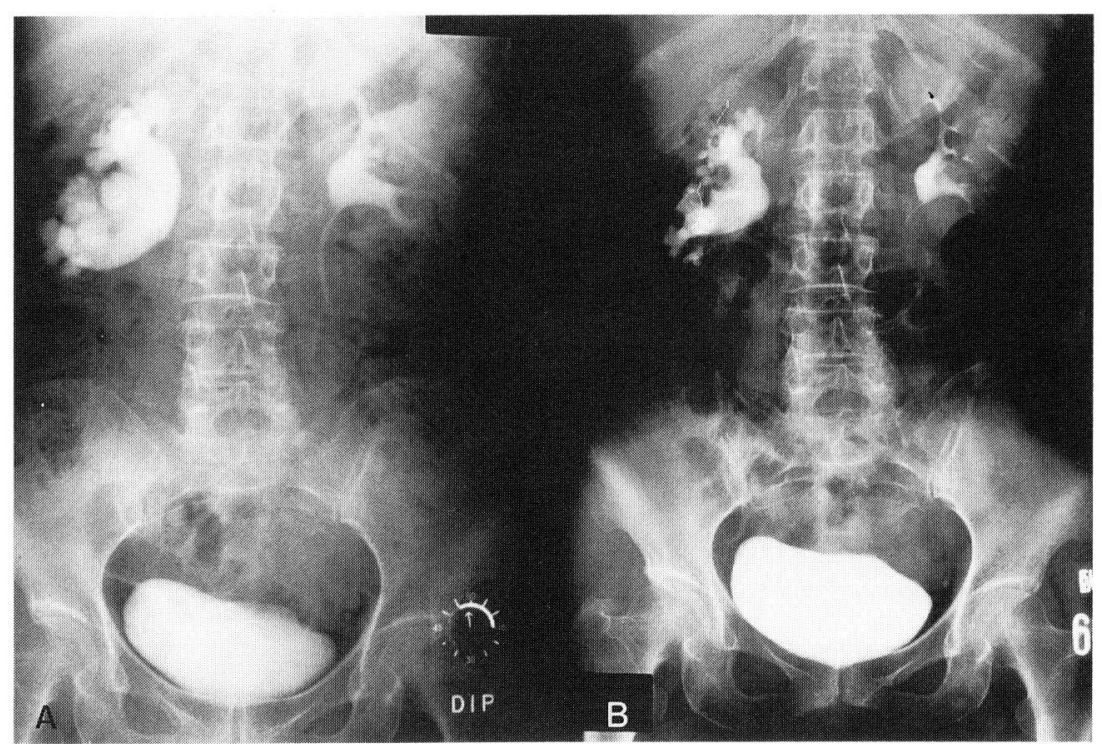

が 1 尿管，尿管ステント留置を継続しているものが 1 尿管，経過観察しているものが 3 㽷管であった。なお 増悪例は中部尿管症例で, 術後 3 力月で改善していた にもかかわらず， 6 力月後水腎症の増悪がみられ, 現 在経過観察が行われている.

\section{考察}

内視鏡的腎孟切開術は percutaneous pyelolysis ${ }^{3)}$, percutaneous pyeloplasty ${ }^{10)}$, endopyelotomy ${ }^{6)}$ など 呼ばれ, Davis ${ }^{11} の$ 考案した intubated ureterotomyの
よらに，腎而尿管移行部の狭窄部の切開を尿路内腔よ り行なら内視鏡的手術である。本法は開放性手術に比 し，侵襲が少なく，腎盂尿管周囲の外科的剝離操作を 必要としないため, 腎盎尿管の血行障害を引き起こす ことがないといわれている12). 通常, 腎需尿管移行部の 後側壁を全層切開 ${ }^{3)}$ ，狭窄部の遠位・近位の左常尿管 まで $1 \mathrm{~cm}$ 程度長めに切開し，この5ち，30F 拡張バル ンカテーテルによる拡張を行い，尿管ステントを 4 な いし 6 週間留置しておくことが勧められている ${ }^{13)}$. 一 
Fig. 6 DIP of 8 year-old-boy with primary ureter opelvic junction obstruction. A. Before. B. After. Postoperative pyelogram demonstrates evident excretion of the contrast medium and patent caliber of ureteropelvic junction.

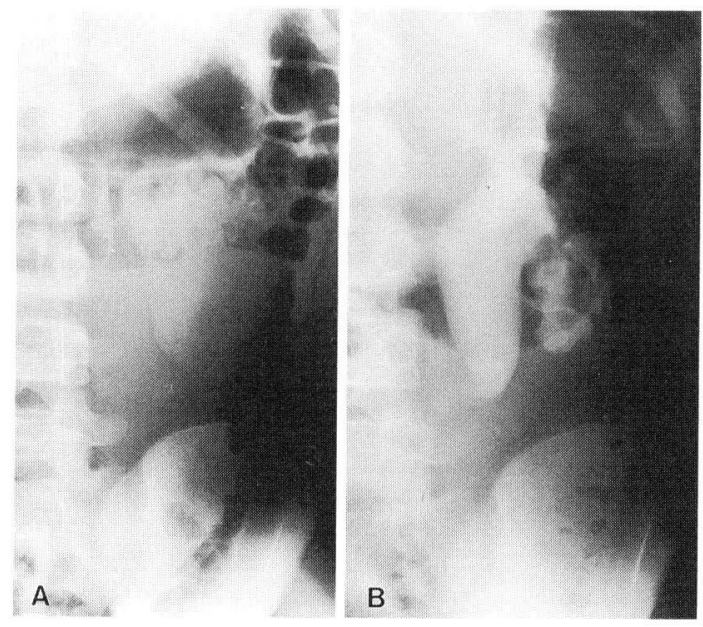

Fig. 7 DIP of 17-year-old man with primary ureteral strictures of solitary kidney. A. Before. B. After. Postoperative pyelogram shows resolution of pyelocaliectasis.

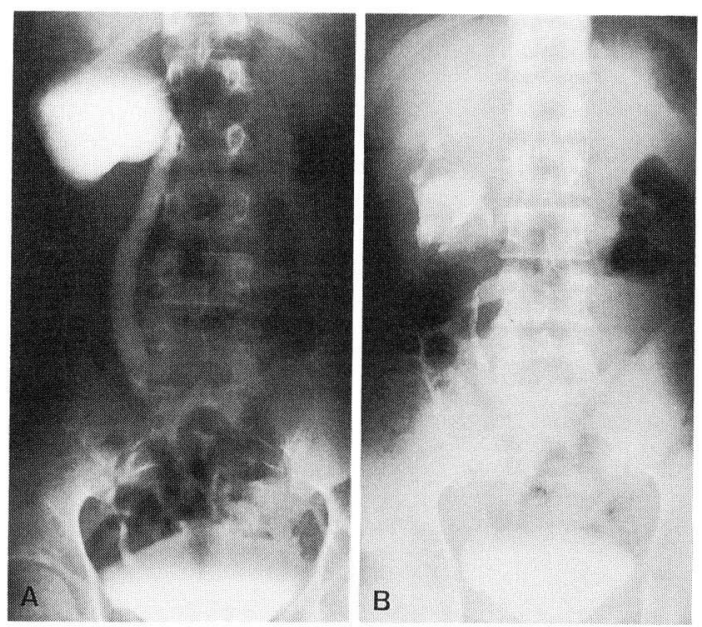

方，我々は中部および下部尿管の狭窄症では側壁，膀 胼近接部では前内側壁を切開している.一般に術後狭 窄例では腎孟尿管周囲は症痕化しており脂肪組織の確 認は困難であるが，狭窄部は硬い組織のため，切開は 容易である.現在, 腎盀切開術には electrorode や cold knife が用いられている。前者は軟性鏡での使用が可
能 ${ }^{24)}$ で, 切開操作のコントロールが容易と考穴られる が，組織の熱損傷を引き起こすので用いるべきではな (、6)15) と考兄られ, opitical urethrotome ${ }^{3)}$ や硬性腎孟 鏡用に作られた pyelotome ${ }^{5)}$ な゙の cold knife が使用 されている。しかし，一般に入手可能な機器では硬性 鏡を用いるため，腎盎の切開局所は必ずしも観察が可 能ではなく，とくに尿管の切開は不可能である。そこ で我々はワイヤーガイド可能な軟性の切開刀を試作 ( ${ }^{7)}$, 内視鏡的に腎杯, 腎孟, 上部尿管の切開を行って きた。 また 0.018 inchのガイドワイヤー插入可能な細 径の軟性切開刀を用いて硬性尿管鏡やファイバーによ る内視鏡的尿管切開術を行った。この軟性切開刀を使 用すると, ガイドワイヤーを常に腎瘻, 尿管, 外尿道 ロと wire loop した状態で全操作を行うことにより， 中腎杯あるいは下腎杯からのアプローチでも腎孟㽷管 移行部拈よび尿管の切開が確実に操作でさ,さらに透 視下コントロールのみで尿管切開が可能となり, 術後 の尿管ステントの插入も容易となる.

現在までに腎孟尿管移行部狭窄症に対する内視鏡的 腎血切開術の検討は少ないが Ramsey ら ${ }^{16)} 18$ / 26 (64\%), Badlani $5^{5)} 27 / 31$ (80\%), Korth $5^{4)} 56 /$ $66(85 \%)$ と良好な臨床成績が報告されている。本法 は術後腎盂尿管移行部狭乍症, 腎而形成術不成功例, 原発性腎盂尿管移行部狭窄症，腎血尿管移行部狭窄症 に伴ら腎盂結石症に適応があるといわれている617). 原発例と続発例での臨床成績の差はみられないとの報 告17) もあるが, Korth ら ${ }^{4)} の$ 多数例の検討では, 開放性 腎孟形成術後などの続発性腎需尿管移行部狭窄症では その成績は $89 \%$ ，原発例の75\%に比し優れていると 報告している。腎血形成術などの術後腎盘尿管移行部 狭窄症では狭窄部組織の血行は乏しく, 開放性手術に よる剥離操作はさらに血流障害を引さ起こすものと考 えられ，内視鏡的手術の意義は大きいと考光られる。 一方, 巨大腎盂例, 尿管高位付着例, 狭窄部の長い例, 異常血管に起因する例では相詨的適応外といわれてい $\Xi^{6)}$ が, これらの症例の成功例も報告されて扣り ${ }^{12)}$, 今 後, 長期観察により本法の適応は臨床的に確立されて いくものと考えられる.

本法の長期観察例は少ないが，不応例は尿管ステン ト技去後早期に現れるといわれ19)，これまでの検討で は成功例の再狭窄の報告はみられないが，今回の検討 症例の中で中部尿管狭窄症の 1 例が術後 6 力月で増悪 したが，尿管鏡による粘膜生検では明かな悪性所見な ぞの異常は認めて抢らず, 外因性狭窄症の可能性も考 
慮し，経過観察とともに原因を追求したい．本法初回 失敗例に扣いても再度切開を行って良好な成果を得て いる報告 ${ }^{12)}$ ，失敗例に通常の開放性腎孟形成術を行

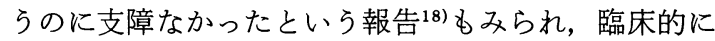
腎孟尿管移行部狭窄症の first choice として推奖され ている。我々は 1 例に Anderson-Hynes's pyeloplasty を施行したが，軽度な線維性癒着を認めたのみで，切 開局所の剝離操作は可能であった。

本法の合併症として Korth $ら^{4)}$ は発熱 $\left(38^{\circ} \mathrm{C}\right.$ 以上) $52 \%$, 輸血 $(1,000 \mathrm{ml}$ 以上) $8 \%$, 気胸 $6 \%$ と報告して いる. 今回の検討では輸血を要したのは 10 歳男児の 1 例にみられたに過ぎなかったが，尿管ステントによる 逆流や閉塞に起因寸ると考えられる術後腎孟腎炎が 17\%にみられた。これは入院期間の短縮，外来での簡 便な管理を目的に，小児例以外では敢えて double pigtail type の internal stentを使用したためと思われ る。このような逆流による腎孟腎炎を併発しないよう に，遠位端が尿管に留まるような external stent を推 奖するものもみられる4). しかし今回の検討症例の ち，スプリントカテーテルを留置した成人例と $8 \mathrm{~F}$ multi-length stent (Cook Urological Inc. , USA) の膀腃への插入が不可能で，止む応得ず尿管内にとど めた 9 カ月男児の 1 例に怙いて，カテーテル遠位端の 刺激による尿管粘膜の浮腫をきたし，下部尿管の閉塞 がみられた。 なた Smith universal stent (Cook Urological Inc. , USA) 插入に際して, peel-away sheath による尿管断裂も報告 ${ }^{199}$ されており，尿管ステ ント留置に伴ら合伴症は少なからずみられ，いまだ本 法の術後に適したステントはなく, 今後, 逆流を防止 でき，插入の容易なステントの開発が望まれる。

小児例に対しては本法の臨床的意義は不明である が, Badlani (1988) ら ${ }^{199}$ は 5 歳以上の腎冓管移行部狭 窄症例すべてに対し, 本法が first choice の治療法とし て報告している。我々も小児 (15歳未満) の 6 尿管に 本法を施行した。このらち前述したステントによる尿 管閉塞をきたした 9 カ月男児例では尿管拡張術を行 い，良好な経過を得られたが，5歳未満の小児では尿 管径が小さいので適切なステント留置が不可能と考兄 られ，本法には限界があると思われ，長期観察も含め， 今後は慎重に対処していきたい。

内視鏡的あるいは透視下尿管切開術は, 尿管切石術 などの術後尿管狭窄症やその他の原因による尿管狭窄 症に対しても 7 尿管中 5 尿管 (85\%) と良好な成績が 得られ，とくに尿管抎張術不応例にも有用であった。
一方，我々の少数例の尿管腸管吻合部狭窄症に対する 成績は $29 \%$ と不良で，本法は臨床的に限界があると考 えられたが, Kramolowsky ら ${ }^{199}$ は軟性鏡に electrode を用い尿管腸管吻合部狭窄症 7 例のらち 5 例（71\%） に改善がみられたとし，本法は短期の入院で可能で, 出血量, 術後疼痛, 合併症が少ないことからまず試み てよい手段であると報告している。現在，我々は尿管 腸管吻合部狭窄症に対し， $14 \mathrm{~F}$ 程度の口径の留置ステ ントを使用し，留置期間も 8 週程度と長期にすること を試み，臨床的に良好な感触を得ており，今後，さら に検討していきたい。

最近，腎孟尿管移行部狭窄症や尿管狭窄症に対して 経尿道的腎盂尿管切開術が行われ，80\%以上の臨床成 績が報告されている ${ }^{20)}$ ．またワイヤーガイド可能な尿 管切開刀が各社より市販されるようになり，この経尿 道的尿管腎孟切開術は従来の経皮的腎孟切開術に比 べ，より侵襲が少なく，臨床的に有用な内視鏡手段と 期待される。

\section{結 語}

1. ワイヤーガイド可能な軟性の切開刀を試作し, 年 齢 9 カ月より 76 歳（平均 $36.2 \pm 23.8$ 歳）の32例（34尿 管)の腎盂尿管移行部狭窄症沶よび尿管狭窄症に対し, 内視鏡的腎孟尿管切開術あるいは透視下尿管切開術を 行った。

2、ステント技去後 3 カ月を経過した 34 尿管中 25 尿 管 (74\%) に閉塞性変化の改善が認められた。改善例 の観察期間は $3 \sim 43$ 力月, 平均 $11.7 \pm 10.0$ 力月であっ た.

3. 成因別には先天性腎孟尿管移行部狭窄症では16 尿管中 13 尿管 (81\%)，後天性腎孟尿管移行部狭窄症て は 4 尿管とも，尿管狭窄症では 7 㽷管尿中 6 尿管 (85\%)，尿管腸管吻合部や尿管膀羘吻合部の狭窄症で は 7 尿管中 2 尿管 (29\%) に改善がみられた。

4. 術中輸血を要する出血が 1 例にみられた以外, 重 篤な合併症は経験しなかった。

以上，試作した軟性切開刀を用いた内視鏡的腎孟尿 管切開術あるいは透視下尿管切開術は腎盂尿管移行部 狭窄症や尿管狭窄症に対し，侵襲の少ない有用な尿路 形成術と考えられた。

本文の要旨は第 3 回日本 Endourology $E S W L$ 研究会お よび第 7 回中部 IVR 研究会に打いて発表した.

\section{文 献}

1) Banner, M.P. and Pollack, H.M.: Dilatation of ureteral stenoses: Techniques and experi- 
ence in 44 patients. Am. J. Roentgenol., 143, 789-793, 1984.

2) 竹内敏視, 石原 哲, 篠田育男, 林 秀治, 山羽正 義, 栗山 学, 兼松 稔, 坂 義人, 河田幸道: 尿 管狭窄症に対するバルンカテーテルによる尿管拡 張術。西日泌尿，51，505-509， 1989.

3) Whitfield, H.N., Mills, V., Miller, R.A. and Wickham, J.E.A.: Percutaneous pyelolysis: An alternative to pyeloplasty. Br. J. Urol., 00, 93-96, 1983.

4) Korth, K., Kuenkel, M. and Erschig, M.: Percutaneous pyeloplasty. Urology, XXXI, 503-509, 1989.

5) Badlani, G., Eshghi, M. and Smith, A.D. : Percutaneous surgery for ureteric junction obstruction (endopyelotomy): Technique and early results. J. Urol., 135, 26-28, 1986.

6) Smith, A.D. and Badlani, G.H.: Percutaneous ureteral surgery : Stenosis, stones, and baskets. in New Techniques in Urology, ed. by White, R. W.D. and Palmer, J.M., 1st ed., Futura Publishing Company, New York, 1987.

7）竹内敏視, 河田幸道：内視鏡的腎昷切開術のため の軟性切開刀。臨泌，41，1052，1987。

8）川村寿一, 伊藤 担, 王 本欽, 吉田 修, 藤田 透：腎シンチグラフィーによる閉塞性腎疾患 (Obstructive nephropathy) の残存腎機能の評価. 泌尿紀要, 26, 967-977, 1980.

9）江左篤宣, 杉山高秀, 朴 英哲, 永井信夫, 金子茂 男, 井口正典, 秋山隆弘, 栗田孝：上部尿路 Dynamicsからみた腎盎形成術の評価。日泌尿会 誌, 78, 2161-2167, 1987.

10) Korth, K.: Percutaneous Surgery of Kidney Stones. 1st ed, p. 73-77, Springer-Verlag, Berlin, 1984.

11) Davis, D.M. : Intubated ureterotomy: A new operation for ureteral and ureteropelvic strictures. Surg. Gynecol. Obstet., 76, 513-518, 1943.
12）藤沢 真, 森川 満, 佐々木正人, 宮田昌伸, 金子 茂男, 徳中荘平, 八竹 直, 稲田文衛: 先天性腎血 尿管移行部狭窄症に対する内視鏡的狭窄部切開 術. 日泌尿会誌, 79，994-1001，1988.

13) Brannen, G.E., Bush, W.H. and Lewis, G.P. : Endopyelotomy for primary repair of ureteropelvic junction obstruction. J. Urol., 29-32, 1988.

14) Clayman, R.V., Hunter, D., Surya, V., Castaneda-Zuniga, W.R., Amplatz, K. and Lange, P.H.: Percutaneous intrarenal electrosurgery. J. Urol., 131, 864-867, 1984.

15) El-Mahrouky, A. Ford, K.K., Moore, A.V. Jr., Shore, N. and King, L.R.: Balloon dilatation of ureteral strictures in dogs. J. Urol., 131, 582-586, 1984.

16) Ramsey, J.W.A., Miller, R.A., Kellett, M.J., Blackford, H.N., Wickham, J.E.A. and Whitfield, H.N.: Percutaneous pyelolysis : Indications, complications and results. $\mathrm{Br}$. J. Urol., 56, 586-588, 1984.

17) Cangh, P.J.V.: Endourological Treatment of Ureteropelvic Junction Obstruction. In Abst. 7th World Congress on Endourology and ESWL. p. 48, 1989.

18) Badlani, G., Karlin, G. and Smith, A.D.: Complications of endopyelotomy : Analysis in series of 64 patients. J. Urol., 140, 473-475, 1988.

19) Kramolowsky, E., Clayman, R.V. and Weyman, P.J. : Management of ureterointestinal anastomotic strictures: Comparison of open surgical and endourological repair. J. Urol., 139, 390-394, 1987.

20) Clayman, R.V., Basler, J.W., Kavoussi, L.R. and Denstedt, J.D.: Ureteronephroscopic Endopyelotomy. In Abst. 7th World Congress on Endourology and ESWL. p. 120, 1989.

(1990年 8 月 9 日受理) 